Niezaleizny badacz

Bielsk Podlaski

https://orcid.org/0000-0002-6530-8183

\title{
Исторический очерк о сакральных объектах на территории православного прихода Вознесения Господня в Клейниках
}

В настоящей статье предпринимается попытка проанализировать историю происхождения сакральных объектов на территории православного прихода в Клейниках. Данная проблематика - иногда по объективным причинам - представлена исключительно фрагментарно.

Местная легенда и другие устные предания гласят:

(...) После разорения стольного града Киевской Руси, учиненного войсками Хана Батыя в 1240 году, уцелевшие православные иноки, спасаясь от неизбежной и мучительной смерти, вдохновленные избавительной силой Божьей, бежали на запад. После многих месяцев скитаний они добрались до недоступных болот, находящихся в непроходимых лесах, где и постановили искать убежище. Остановившись на небольшом холме, один из монахов решил поискать у его подножия воду, чтобы утолить жажду. Подкрепившись этим Божьим даром, братья поблагодарили Господа молитвой и постановили отдохнуть перед дальнейшими странствованиями. Утром, проснувшись с восходом солнца, все братья почувствовали необыкновенный прилив сил. Они посчитали это знаком Божьим. Решили остаться у источника, где нашли воду, и собственноручно построить для себя жилище, то есть кельи. А на вершине холма поставили часовню. В скором времени весть о благочестивых иноках разнеслась среди близлежащих поселений, разбросанных там и сям среди лесных дебрей. Иноков из этих келий начали называть келейниками (...).

Из-за отсутствия каких-либо источников невозможно установить даже приблизительную дату постройки первой церкви в селе Клейни- 
ки. В свою очередь, в Наревской пуще был когда-то монастырь Вознесения Господня, основанный на территории села Одринки между 1607 и 1617 годами ${ }^{1}$. Монастырь был основан на территории, на которой была развита монашеская жизнь в виде отшельничества. Также и эта церковь в Клейниках была освящена в честь Вознесения Господня. Первое письменное упоминание о клейникской церкви появилось в 1568 году, когда король Зигмунд Август 16 марта упомянутого года передал церкви две "волоки", состоящие из трех полей, что в 1691 году подтвердил стольник великий коронный Стефан Николай Браницкий ${ }^{2}$. А первая запись о духовном отце Клейникского прихода была сделана в 1560 году в описании визитации в Нарве, в которой отмечено, что "клейникский поп" владел недвижимостью, расположенной в этом городе на улице Бельской ${ }^{3}$. Это позволяет констатировать тот факт, что первая церковь на описываемой территории существовала задолго до этого времени.

\section{Церковь Вознесения Господня}

До Брестской унии, принятой в 1596 году, церковь в Клейниках была православной. С момента заключения Брестской унии сельский Клейникский приход оказался в юрисдикции Униатской Церкви. Изменения в убранстве церкви на латинский лад в этот период отлично иллюстрирует «Wizyta Generalna Cerkwie Klenickiey pod tytułem Wniebowstąpienia Pana Naszego Iezusa». Составленная в этом году опись информирует о том, что:

(...) Cerkiew drewniana dostatnia ieszcze niestara z połową kopuły pod Dachem dranicznym ieszcze trzymającym się. Cmętarz wkoło oparkaniony z fortą zamczystą pod Daszkiem opatrzona. Krzyż na cmętarzu wielki z wierzchu ze... przykryty z krzyzykiem zelaznym. Dzwonica separatim od Cerkwie na słupkach wiązana zbyt stara pod Dachem ogniłym. Babiniec za iedną z sscianą Cerkiewną do ktorego Drzwi wielkie na zawiasach z zamkiem wnętrznym y drugim wiszącym. Drzwi do samey Cerkwie wakuią. Chor nad całym babincem dostatni. Cerkiew wielka per medium kościoła Rzymskiego do...robiona.

1 A. Mironowicz, Życie monastyczne w Rzeczypospolitej, Białystok 2001, s. 107-113; tenże, Monaster Przemienienia Pańskiego w Puszczy Narewskiej, [w:] "Białostocczyzna", Białystok 1990, № 19, s. 37-38.

2 Lustracje województwa podlaskiego 1570 i 1576, wyd. J. Topolski i J. Wiśniewski, Warszawa-Wrocław 1959, s. 56.

3 G. Sosna, Dekanat narewski. Klejniki, [далее: Dekanat narewski...], [w:] "Е $\Lambda$ Пг", Białystok 2000, Zeszyt 3 (16), s. 246. 
Okien w niey siedm w Ołow robionych iedne z nich za kratą zelazną. Pawiment, stela, kratki kryłoszy Pulpitow dwa do ksiąg. Stoł z szufladami okowanemi, Ławki wszystko to gładkiey roboty porządne. Item Ławka ad...Confessionału Skrzynia bracka okowana zamczysta. (... ${ }^{4}$.

На основании этой описи можно сделать вывод, что внешний вид святыни был далек от привычных восточных украшений. Самым значимым в униатских церквях стал демонтаж иконостаса: (...) Carskich drzwi ani Deisusu nie ma. Apostoty-obrazy Deisusowe-różnie po ścianach cerkiewnych porozmieszczane. Przed kryłosami obrazy dwa, jakoby namiesne, z oltarzykami ubogo urzadzonymi $(. . .)^{5}$ и иконы, представляющие несколько другой характер и композицию представленных на них святых, не встречающиеся до тех пор в приходских сакральных объектах, далекие от канонической православной символики ${ }^{6}$. Кроме того, также упоминается о чуждом для Восточной Церкви боковом алтаре, лавках, исповедальне, деревянной кропильнице со святой водой, ковчеге для святых даров и распятиях. Униатская Клейникская церковь также имела амвон ${ }^{7}$.

Оснащение церкви литургическими сосудами и другими предметами церковной утвари было совсем небогатым. В заметке, составленной по итогам визитации, говорится:

(...) Kielich, Patyna, Łyzeczka y gwiazda Srebrne białe, na kielichu pomienionym $\mathrm{w}$ (... Pukiet $\mathrm{z}$ puklami pozłocisty. Na Ewangely Srebro po rogach tabliczek cztery piąta w promieniach wielka. Puklow cztery y klauzurek sztuk cztery. Puszka cum Vbti cynowa. Miernica cynowa dwoista. Ampułek cynowych dwie przystawka cynowa iedna. Lichtarzow cynowych wielkich Ołtarzowych dwa. Lichtarzow cynowych stołowych cztery. Kadzielnicy mosięzne dwie. Lichtarzow Mosiężnych sporych stołowych cztery. Dzwonow miernych na Dzwonicy Pięć. Dzwonków Małych u Ołtarza trzy. Koron blaszanych dwie. Lichtarz zelazny Na łancuchu wiszący. Zelaza od krat sztuk dziewięć. Krzyz wielki z...z kopuły, kuna zelazna y szczepce do swiec żelazne. $(. . .)^{8}$.

4 Wojewódzkie Archiwum Państwowe w Lublinie [далеe: WAPwLublinie], Wizyty dekanatu bielskiego, cerkiew klejnicka [далее: Wizyty dekanatu...], syg. 780, k. 402-403.

5 Там же.

6 Больше на тему истории Клейникского прихода в период Унии, см.: A. Kuprianowicz, Уния и реституиия православия на территории православного прихода Вознесения Господня в Клейниках, "Białorutenistyka Białostocka", Białystok 2019, s. $251-266$.

7 I. Matus, Obraz Cerkwi unickiej w obwodzie białostockim na poczatku XIX wieku, "Studia Wschodniosłowiańskie", Białystok 2015, t. XV, s. 600.

8 WAPwLublinie, Wizyty dekanatu..., syg. 780, k. 402-403. 
Как показала генеральная визитация святыни, в XVIII и в начале XIX века материальное положение униатской церкви в Клейниках было не наилучшим. Она требовала незамедлительного и основательного ремонта. Когда в 1839 году униаты возвратились в православие, униатская церковь в Клейниках снова стала православной святыней. Это означало введение очередных изменений в ее устройство. Ее чрезвычайно скромное убранство, оставшееся еще с униатских времен, начало восполняться элементами, характерными для святынь православного вероисповедания. В то время клейникская церковь не имела предметов церковной утвари для совершения богослужений в соответствии с греко-восточным литургическим обрядом. Недостающими литургическими сосудами оказались: дискос, звездииа, дарохранительница, копия, напрестольный крест, кадильница, два серебряных бокала для вина и воды для Святого Причастия, сосуды с прибором, необходимым для ночной службы ${ }^{9}$. Не было медной чаши, служащей священнику для омовения рук перед Божественной Литургией. Также нужны были по паре больших лампад и подсвечников перед иконами Иисуса Христа и Богородицы, лампады перед царскими вратами, большой подсвечник для свечи на время чтения Евангелия, два покрыьвала и воздух из хорошей ткани, Евангелия ${ }^{10}$. В 1836 году было начато устройство и установка иконостаса ${ }^{11}$. В это трудное время бесценной оказалась материальная помощь от многих прихожан. За пожертвования, собранные прихожанами, было куплено много новых, ценных и необходимых предметов церковной утвари для совершения богослужений. Кроме литургических сосудов, за эти деньги в Москве были куплены, в частности, колокола весом 42 пуда и 17 фунтов (около 680 килограмм), икона Покров Пресвятой Богородицьи, икона Св. Троица, икона Св. Николай Угодник и икона Рождество Христово, а также паникадило, пасхальный трехсвечник, алтарный крест и подсвечник на семь свечей ${ }^{12}$.

Понимая просто трагическое материальное состояние объекта, 31 августа 1879 года прихожане, посовещавшись с тогдашним духовенством, объявили конкурс на строительство новой церкви и приход-

9 I. Matus, Schylek unii i proces restytucji prawosławia w obwodzie białostockim w latach 30. XIX wieku, Białystok 2013, s. 243.

10 Цит. за.: tamże, c. 243.

11 G. Sosna, Klejniki, "Wiadomości Polskiego Autokefalicznego Kościoła Prawosławnego" [далее: WPAKP], Warszawa 1987, № 1, s. 63.

12 «Литовские Епархиальные Ведомости» [далее: ЛЕВ] 1874, № 10, с. 73; А. K u prianowicz, Dzieje parafii prawostawnej pw. Wniebowstapienia Pańskiego w Klejnikach od XIX do polowy XX wieku, [w:] "Białoruskie Zeszyty Historyczne", Białystok 2018, № 49 , s. 65 . 
ских сооружений на сумму 1785 рублей ${ }^{13}$. В начале 80 -х годов XIX века началось строительство новой деревянной церкви. Торжественное освящение краеугольного камня состоялось 4 июня 1880 года. Стоимость строительства церкви составила 8800 рублей. Мастерами, занимающимися строительством святыни, были Франц Майер из Пруссии, Иоанн Куприянович из Нарвы, Иоанн Буслович из Бельска Подляшского и Иоанн Пугацевич из Шастал ${ }^{14}$. Торжественное освящение новопостроенной приходской святыни в Клейниках состоялось 4 сентября 1883 года. Ее архитектура представляет собой три огромных крыла, что визуально увеличивает масштаб церкви. Церковь была построена в типичном для России "казенном" стиле. Иконы, написанные в старорусском стиле, украшали и придавали таинственность всему ее пространству. Средства на ее строительство были собраны за счет пожертвований щедрых прихожан в размере 13.000 рублей и государственной ссуды в размере 795 рублей ${ }^{15}$. Значительную сумму - 120 рублей - передал на строительство государственный служащий Н.Ф. Маковеевский. А один из жителей прихода пожертвовал серебро стоимостью 100 рублей ${ }^{16}$. В 1892 году внутреннее убранство новопостроенной церкви пополнилось двумя металлическими хоругвями, купленными за 155 рублей ${ }^{17}$. Одной из гордостей святыни был превосходный барельеф, размещенный над царскими вратами. К сожалению, все это сгорело во время пожара церкви 6 апреля 1973 года. Церковь XIX века сгорела дотла вместе со всем ее богатым убранством. В огромном пожаре уцелело только Евангелие, серебряный бокал и напрестольный крест ${ }^{18}$.

После трагического события прихожане незамедлительно приняли решение о строительстве новой, каменной церкви. Энтузиазм прихожан и готовность жертвовать быстро принесли видимый результат. 23 мая 1974 года состоялось освящение краеугольного камня под строительство новой святыни. Во время рытья траншеи под фундамент рабочие наткнулись на засыпанное землей пожарище, внутри которого нашли фрагменты человеческих костей. Их сложили в один большой гроб и закопали глубоко под полом строящейся в то время святыни.

13 ЛЕВ 1879, № 32, с. 255; 1880, № 25, c. 202.

14 Нацыянальны гістарычны архій Беларусі ӱ Гродне, ф. 135, оп. 1, д. 75.

15 G. Sosna, Klejniki..., s. 64.

16 Ф. Сосновскій, Освященіе Кленинской Вознесенской черкви, Бъльскаго уъзда, 4-го сентября, [w:] ЛЕВ 1883, № 40, с. 359.

17 ЛЕВ 1892, № 29, с. 240.

18 По рассказу батюшки. А. Высоцкого. 
Можно предположить, что предыдущие церкви также могли сгореть в пожарах. Импульсом для быстрого строительства новой святыни стало чудо обновления надвратной иконы Богородицы, размещенной над входными воротами (с наружной стороны стены), ведущими на территорию церкви, на так называемый ивинтар (погост). Василий Тополевский так вспоминает это событие: (...) был тепльий летний вечер. Разразилась сильная гроза и начался дождь с градом. Во время грозы над иконой появился яркий столб света, который удерживался длительное время. При этом икона начала изменять ивет своего облачения. Свидетелем этого чуда стал Василь Калиновский - уже умерший житель хутора Буриике (... ${ }^{19}$. Известие о необычном чудесном событии быстро распространилось среди близлежащих приходов. Икону сняли с ворот и повесили в новопостроенной церкви над царскими вратами. Каждый год в Великую пятницу перед Пасхой в церкви совершается торжественная служба. На ней поется Акафист Божией Матери. Икона опускается, чтобы верные могли приложиться к иконе (поклониться и поцеловать). В 2004 году икона была перенесена в Часовню Успения Богородицы в местной церкви. А вместо нее была установлена икона Богородицы, привезенная из Почаевской лавры.

Первый, начальный проект новой церкви разработал Адам Сталоны-Добжанский. Дальнейшие работы над проектом этого сооружения велись инженером-архитектором Ириной Малафеевой, которая также руководила его дальнейшей реализацией. Новая церковь была построена на плане креста. Это трехнефное сооружение, с двумя рядами колонн, разделяющими между собой отдельные нефы. Внутри церковь имеет крестовой свод и узкие высокие окна, напоминающие средневековую оборонную архитектуру. Святыня увенчана одним центральным куполом и колокольней, конструкция которой соединена с остальным зданием. Внутри здания, в его верхней части, рядом с местом, предназначенным для хора, находится небольшая часовенка с отдельным входом. Ризница располагается рядом с алтарем. Несмотря на огромные трудозатраты и использование труднодоступных в тот период строительных материалов, громаду сегодняшней церкви Вознесения Господня нельзя отнести к удачным. Она представляет собой сочетание стилей каменной церковной архитектуры периода Киевской и Галицко-Волынской Руси. Ее характеризует в основном российский стиль церковного строительства XIX века. Этот характер стиля проявился после строительства колокольни, размещенной над притвором.

19 По рассказу Василия Тополевского, жителя села Клейники. 
K отрицательным моментам стоит также отнести плохую акустику внутри святыни во время совершения богослужений.

Несмотря на перечисленные недочеты, строительство церкви стало очень важным событием, поскольку свидетельствовало не только о силе православной веры, но и вводило в сельский пейзаж Подлясья малоизвестные до сих пор элементы. Монументальность церкви вместе с использованными в ее глыбе элементами и многовековыми традициями русской школы церковного строительства является очень ярким свидетельством привязанности прихожан Клейникского прихода к тысячелетним традициям православного христианства, привитого в 988 году тогдашним Святым равноапостольным киевским князем Владимиром Великим.

Основные работы, связанные со строительством новой церкви, продолжались до конца 70-х годов. Первая Божественная Литургия была совершена тогдашним настоятелем, протоиереем Яном Юзвуком в день памяти Св. Параскевы Сербской 27 октября 1979 года. Дальнейшие работы продолжались и в $80-\mathrm{x}$ и в 90-х годах $\mathrm{XX}$ века уже при новом настоятеле этого прихода отце Александре Высоцком, который приступил к пастырской деятельности 23 марта 1980 года. 1981 год знаменателен завершением двухлетних работ, связанных со строительством и устройством иконостаса. Исполнителем рамы его конструкции по проекту Адама Сталоны-Добжанского был резчик цыганского происхождения Иоанн Плоньский из Фаленицы. Автором же икон был греческий мастер-иконописец Сотирис Пантопулос. В 1984-1986 годах конструкцию иконостаса покрыл золотом Юрий Щигол. В окна пресбитерия были вставлены витражи, также по проекту А. Сталоны-Добжанского, а полихромию в пресбитерии выполнил болгарский художник из Софии Асан Гицов. Алтарь из полевого камня изготовил Сергиуш Мартынюк из Нарвы на основании проекта Иоанна Соловянюка ${ }^{20}$.

Фундаторами убранства святыни были, в частности, Петр Фирсюк, который пожертвовал в 1979 году большое паникадило, иконы апостолов Петра и Павла и икону апостола Иакова. Дарохранительнииа, которую изготовил Иоанн Илияшук (житель хутора Бурицке), была позолочена золотых дел мастерами из Кракова. В 80-х годах в краковской церкви была куплена и привезена настоятелем А. Высоцким и П. Фирсюком Плащанища. В более поздний период за пожертвова-

20 G. Sosna, Dekanat narewski.., s. 249. 
ния, собранные церковно-приходским хором, было куплено Распятие 21 . В 90-х годах Иоанн Тополевский, житель хутора Бурицке, пожертвовал две большие иконы для приходской церкви в Клейниках и икону Преображение Господне и Распятие Иисуса Христа для местной кладбищенской церкви ${ }^{22} .27$ октября 1988 года, в день памяти Св. Параскевы Сербской, прошло торжественное освящение церкви, которое провел Митрополит Варшавский и всей Польши Василий. По случаю консекрации новой святыни и приходящегося на этот год празднования 1000-летия Крещения Киевской Руси около главного входа в церковь была вмурована памятная таблица. Надпись на ней выгравирована на древнерусском языке периода Киевской Руси. Пластический проект таблицы разработал Леонидас Вишенко, а изготовил таблицу Вячеслав Шум из Семятич ${ }^{23} .1996$ год прошел под знаком золочения крестов, венчающих купол церкви. А в конце 90-х годов все стены святыни были расписаны полихромией. В 2001 году конструкция алтаря (престола) была украшена привезенной из Москвы золотой оправой. Период строительства церкви требовал от прихожан и их тогдашних настоятелей огромных моральных, физических и финансовых усилий. В течение 15 лет (1973-1988) на строительство святыни было израсходовано 146 тонн стали, 234 тонны цемента, 3 железнодорожных вагона извести, $185 \mathrm{~m}^{3}$ древесины и 8 тонн листового металла. Финансовые вложения в строительство составили 14 млн злотых, 756 долларов, 500 франков и 200 марок $^{24}$.

Строительство новой церкви послужило импульсом для визитов не только представителей высшего польского духовенства, но и религиозных общин со всего мира. В июне 1978 года Клейникский приход посетила делегация Греческой Православной Церкви и Эфиопский Патриарх Такел. В июне 1982 года приход посетил Митрополит Американской Автокефальной Православной Церкви Феодосий. В августе 1986 года в Клейникском приходе побывала молодежь, члены Экуменической Межхристианской Организации Филоксения с местонахождением в Швейцарии. Гостями были также студенты теологии из Прешова - главного религиозного и культурного центра украинцев, проживающих на территории Восточной Словакии. В конце 80-х годов при-

21 По рассказу Петра Фирсюка, жителя хутора Тинковщина.

22 По рассказу Иоана Тополевского, жителя хутора Бурицке.

23 G. Sosna, Dekanat narewski..., s. 249.

24 G. Sosna, Parafie prawostawne. Na poczatku byta kelia, "Tygodnik Podlaski", Warszawa 1991, № 7-8/91, s. 23. 
ход посетил представитель Российской Православной Церкви, епископ Пермский и Соликамский Афанасий (уроженец Бельского повета Белостокского воеводства).

\section{Часовня Преображения Господня}

Еще одним сакральным объектом на территории прихода является кладбищенская часовня Преображения Господня. Первая кладбищенская часовня в Клейниках была построена в 1834 году. Фундатором переноса часовни из фольварка Вежанка на приходское кладбище ${ }^{25}$ был Иосиф Иоанн Вильчевский, полковник литовского войска, командир Татарского полка. Согласно «Метрическим книгам» церкви в Лосинке, с 1828 года священником в вежанской часовне служил отец Василий Северинович, викарий из Клейник. С ним связаны некоторые перетурбации с расположением вежанской святыни. Итак, со временем вдова фундатора Екатерина Вильчевская стала неплатежеспособной в отношении отца Севериновича. Долг вырос до 100 рублей серебром. Он, в свою очередь, будучи сам должником, в 1829 году продал часовню Клейникскому приходу за сумму 1100 злотых. Она была разобрана и заново собрана на приходском кладбище без смены названия ${ }^{26}$.

25 G. Sosna, A. Troc-Sosna, Eosinka. Parafia na skraju Puszczy Ladzkiej [далее: Łosinka...], Bielsk Podlaski-Ryboły 2009, s. 186.

26 Kaplica we Dworze tymże zawsze należała do cerki Kleinickey, przy którey regularnie we wszystkich wiadomościach podawna była. Fundator tey kaplicy nieboszczyk JW. Starosta Józef Wilczewski, za życia swego utrzymywał przy niey Kapłanów, z przeznaczeniem rocznem sto złotych pieniędzmi $i$ stotem przyzwoitym dla Kapelana, sprawujacego. $Z$ rzędu tego był najpierwszym, teraźniejszy Paroch Kośniański X. Tarasiewicz w Drohickim Dekanacie na Beneficium Kośna mieszkajacy, po nim Kilka nawrotami zaymowat to miejsce nieboszczyk X. Antoni Głowacki, między tym czasem zaymowali sie X. Mikołaj Odelski $i$ X. Pacewicz także nieboszczycy. Po tych Bazyli Sewerynowicz dzisiejszy obowiazek Wikarego przy Cerkwi Kleinickiey petniacy, na tymże fundamencie co poprzednicy iego utrzymujacy się. Nieboszczyka J.W Starościna Katarzyna Wilczewska otrzymawszy po zejściu męża swego maietności Wieżanka do czasu swey śmierci, utrzymywata tak$\dot{z} e$ na Kapelaniy $w$ Wieżance trzech nadmienionych Kapłanów, z kondycja odprawiania Mszy SS. dni niedzielnych $i$ światecznych za pensya sto złotych pieniędzy $i$ stotem... gdy podupada na dobrem mieniu przez ciag ośmioletni Kapelaniy X. Sewerynowicza w Wie-

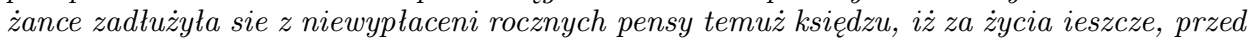
zgonem swoim zrobiła Testament, wszystkich swych ruchomości i wszelkiey pozostałości $i$ inwentarza pomiędzy temi wzmiankowana nie raz Kaplica postawioney kosztem i naktadem funduszów własnych Wilczewskich we Dworze Wieżańskim dla własney swey wygody oddania czci $i$ chwaly Nay wyższemu Stwórcy Bogu, iako ichże własność i realna, prawem sukcesyi dostała sie naybliższey familii. Do tego wpisu testamentowego za exekutorem ostateczney woli nieboszczki JW. Starościny Wilczewskiey był przeznaczony przez nia sama W. Michat Czczkowski Sędzia w pogranicznym Powiatu Brzeskiego blizki Kuzyn, ten 
Переносом часовни заинтересовался епископ Иосиф Семашко, требуя соответствующего объяснения. Клейникский настоятель отец Александер Михневич 29 декабря 1834 года написал по этому делу письмо, в котором, в частности, отметил (...) W. Adam Hryniewicki wraz po zebraniu Kaplicy w Wieżance pobudowat Mtyn deptak na tem mieyscu gdzie stała kaplica. Dattum w Plebaniy Kleynickiey 1834 Roku m-ca grudnia 29 dnia Podpis Paroch Cerkwi Kleynickiey Xiadz Aleksander Michniewicz (... ${ }^{27}$. Пeреписка, выясняющая факт продажи вежанской часовни, продолжалась еще в 1835 году прихожанами клейникской церкви. В начале XX века эта часовня была перенесена под реку Нарев, в село Козлики. В 1912 году на месте предыдущей деревянной часовни была построена новая, каменная часовня с этим же названием. После пожара приходской церкви в 1973 году к небольшой кладбищенской часовне был пристроен $n p u$ твор. Это было необходимо, чтобы можно было совершать все богослужения и принимать исповедь. В то время часовня выполняла роль приходской церкви.

В 2013 году святыня была занесена в Реестр недвижимых объектов культурного наследия Подлясшкого воеводства ${ }^{28}$.

\section{Церковь Святого Николая в Козликах}

На краю небольшого поселения Козлики, на берегу реки Нарев находится восемнастовечная деревянная церквушка, освященная в честь Святого Николая. Эта церковь была возведена в 1793 году ${ }^{29}$. Нельзя исключать, что это была первая христианская святыня в этой мест-

zaś sprzedat te publicznej licytacji wszelkie nobila, sprzedał X. Sewerynowiczowi tękaplice $z$ ten wszystkiem, co $w$ niej byto na zaciagniony przez Tesatorkem pensyjny dtug ze sto rubli srebrem pieniędzy wynoszacy. X. Sewerynowicz będac zadtużonym różnym osobom odsprzedat Parafianom Klienckim na zaspokojenie swych Kredytów, za summem tysiac sto złotych, na które kwit wydal z przyjęcia onych. Ci Parafianie potrzebni byli kupienia tey kaplicy i pragnęli oney z obrębu parafialnego nigdzie nie wypuścić że by filialna Kaplica na zawsze przy cerkwi Kleinickey wieczystem była: z sprawowaniem w niey SS. Sakramentów odprawianiem Stużb Bożych, obchodnie odpustu Przemienienia Pańskiego każdorocznie., См.: Lietuvos valstybès istorijas archyvas [далее: LVIA], ф. 643, оп. 3: Sprawa sprzedaży kaplicy wierzańskiej oraz przeniesienie jej na cmentarz Klejniki, będący częścią posiadłości Wierzanka powiat bielski 1793-1835.

27 Там же.

28 Narodowy Instytut Dziedzictwa: Rejestr zabytków nieruchomych. Woj. Podlaskie-powiat hajnowski (Klejniki, kaplica prawosławna cmentarna pw. Przemienienia Pańskiego, 1912, nr rej.: A-533).

29 Клировые Ведомости Клейникской иеркви на 1959 год. rkps. 
ности, на что явно указывают археологические исследования ${ }^{30}$. Когда в 80-х годах XIX века в Клейниках строилась новая церковь, церковь Святого Николая в Козликах временно выполняла функцию приходской святыни. Когда в 1883 году строительство новой церкви в Клейниках было завершено, старая святыня была разобрана и дополнила устройство-убранство филиальной церкви в Козликах. В конце XIX века появилась мысль построить в Козликах каменную церковь. Идейным вдохновителем этого мероприятия был прихожанин Антип, вывезенный вглубь России за помощь участникам восстания 1863 года. Вероятнее всего, именно оттуда он передал средства на строительство святыни. Остальные средства, необходимые для строительства, были получены из пошлины за сплав древесины по реке Нарев. Однако планы строительства каменной церкви не были реализованы. Молва гласит, что старые царские врата из церкви в Козликах сохранились и в настоящее время находятся в кладбищенской часовне в селе Котлы.

В начале XX века в пользу церкви в Козликах были переданы ценные пожертвования, среди которых были три колокола общим весом 8 пудов и 12 фунтов и икона Святого Николая ${ }^{31}$. Церковь является примером однонефной святыни с небольшой башней квадратной формы, установленной на вершине объекта. Убранство церкви включало несколько ценных восемнасвечных икон и литургических сосудов. До начала 90-х годов XX века церковь была богато оснащена древними иконами еще периода Унии. В ночь с 22 на 23 июля 1992 года в святыни произошла кража. Исчезли 12 ценных икон XVIII и XIX века. Среди них были наиценнейшие иконы в стиле барокко «Воскресение Христово» и «Вход Господень в Иерусалим» ${ }^{32}$. Драгоценные иконы были утрачены навсегда. Чтобы защититься от очередных взломов и краж, в церквях в Козликах и Клейниках в 90-х годах была установлена сигнализация и была составлена подробная опись недвижимого имущества всех приходских часовен.

30 декабря 1987 года святыня была занесена в Реестр недвижимых объектов культурного наследия Подляшского воеводства ${ }^{33}$.

30 D. Krasnodębski, Tajemnica kurhanów z Koźlik, "Nad Buhom i Narwoju", Bielsk Podlaski 1998, № 3/4, s. 39-40.

31 Гродненские Епархиальные Ведомости 1915, № 1, с. 10.

32 Cм.: Cerkiew bez ikon. Wielka kradziė̇ w Koźlikach, "Kurier Poranny", 28.07.1992, № 160, s. 1-3; D. Stankiewicz, Dobra utracone. Zabytki ruchome w cerkwi w Koźlikach, [w:] "Biuletyn Konserwatorski woj. białostockiego", Białystok 1995, s. 85-88.

33 Narodowy Instytut Dziedzictwa: Rejestr zabytków nieruchomych. Woj. Podlaskie-powiat hajnowski (Klejniki, cerkiew pw. św. Mikołaja w Koźlikach nr rej.: 674). 


\section{Часовня Николая Чудотворца в Клейниках}

Очередным сакральным объектом на территории прихода является каменная часовня Николая Чудотворца, расположенная в самом центре села. Устные предания гласят, что она была построена около 1865 года. Однако нет никаких письменных упоминаний, подтверждающих достоверность данной информации. А в печатных источниках часовня впервые упоминается в 1905 году ${ }^{34}$.

Здание было построено на плане прямоугольника в стиле классицизма. В качестве строительного материала использовались кирпич и камень. При расширении главной улицы в 50-х годах XX века оказалось, что прокладка дорожного полотна предполагалась по территории, на которой располагалась часовня. В результате чего его владельцем стала Дирекция национальных дорог в Белостоке. В 1992 году были приложены старания к тому, чтобы вернуть часовню во владение православного прихода в Клейниках. В конце концов, документом от 9.04.1992 года было получено согласие на бесплатную передачу части участка размером 9,6 х 10,2 м, на котором располагалось историческое здание ${ }^{35}$. Недалеко от часовни находятся могилы неизвестных воинов Советской Армии, погибших во Второй мировой войне и похороненных в этом месте. По местной традиции каждый год на второй день Пасхи в приходской церкви совершается торжественное шествие прихожан в сопровождении священника к могилам воинов, чтобы почтить их память и совершить панихиду за их души.

13 августа 2013 года святыня была занесена в Реестр недвижимых объектов культурного наследия Подляшского воеводства ${ }^{36}$.

\section{Часовня Бориса и Глеба в Кожине}

Самым молодым сакральным объектом на территории Клейникского прихода является небольшая часовня Бориса и Глеба в Доме спокойной старости «Арка» в Кожине.

\footnotetext{
34 Справочная книга Гродненской епархии на 1905 г., Гродно 1905, с. 78.

35 G. Sosna, A. Troc-Sosna, Cerkiewna wlasność ziemska na Białostocczyźnie w XV-XX wieku, Białystok 2004, s. 173-174.

36 Narodowy Instytut Dziedzictwa: Rejestr zabytków nieruchomych. Woj. Podlaskie-powiat hajnowski (Klejniki, kaplica prawosławna pw. św. Mikołaja Cudotwórcy, k. XIX, nr rej.: A-534 z 13.08.2013).
} 
Эта часовня появилась в середине 90-х годов в месте, где когда-то была расположена начальная школа. Когда уменьшилось число детей, школа была перенесена, а ее здание было адаптировано под тюрьму, которая просуществовала до конца 1989 года. После ликвидации тюрьмы осенью 1995 года, на сессии Городского Совета в Бельске-Подлясшком большинством голосов, по просьбе церковного совета Клейникского прихода, которую поддержало Братство Православной Молодежи, было принято решение о передаче здания Клейникскому приходу. В 1996 году здание тюрьмы вместе с соседствующими хозяйственными постройками было нотариально передано гминой Бельск-Подляшский православному приходу в Клейниках ${ }^{37}$. В очень скором времени начались работы, связанные с подготовкой и адаптацией здания к потребностям жильцов. К зданию было пристроено крыло, в котором разместилась часовня Бориса и Глеба ${ }^{38}$. Строительство было завершено в 2002 году. Консекрация часовни была проведена 6 декабря 2002 года в день памяти Святого Александра Невского. Годом позже, 6 декабря 2003 года, в Доме опеки «Арка» под председательством Его Преосвященства епископа Бельского Григория ${ }^{39}$ духовенство Наревского деканата провело Предрождественские реколекции (духовные упражнения) и деканальную конференцию.

\section{LITERATURA}

Cerkiew bez ikon. Wielka kradzież w Koźlikach, "Kurier Poranny", 28.07.1992, № 160 .

Grodnienskije Jeparxialnyje Viedomosti, 1915, № 1 [Гродненские Enархиальнье Ведомости, 1915, № 1].

Klirovyje Viedomosti Kliejnikskoj cierkvi na 1915 god, rkps. [Kлировыее Ведомости Клейникской черкви на 1959 год, rkps.].

Kuprianowicz A., Dzieje parafii prawostawnej pw. Wniebowstapienia Pańskiego w Klejnikach od XIX do połowy XX wieku, "Białoruskie Zeszyty Historyczne", Białystok 2018, № 49.

Kuprianowicz A., Unija i riestitucija pravostavija na tierritorii pravostavnoho prixoda Vozniesienija Hospodnia v Kliejnikax, «Białorutenistyka Białostocka»,

37 По рассказу батюшки Александра Высоцкого.

38 G. Sosna, Dekanat narewski..., s. 250-251.

39 K. Wysocki, P. Łapiński, Przedświateczne spotkania w kożyńskiej "Arce”, Warszawa 2004, WPAKP, № 2 (171), s. 6-7. 
Białystok 2019, t. II [Kuprianowicz A., Уния и реституиия православия на территории православного прихода Вознесения Господня в Клейникax, "Białorutenistyka Białostocka", Białystok 2019, t. II].

Krasnodębski D., Tajemnica kurhanów z Koźlik, "Nad Buhom i Narwoju", Bielsk Podlaski 1998, № 3/4.

Lietuvos valstybės istorijas archyvas, f. 643, op. 3: Sprawa sprzedaży kaplicy wierzańskiej oraz przeniesienie jej na cmentarz Klejniki, będacy częścia posiadłości Wierzanka powiat bielski 1793-1835.

Litovskije Jeparxialnyje Viedomosti, 1874, № 10; 1879, № 32; 1880, № 25; 1892, № 29 [Литовские Епархиальные Ведомости, 1874, № 10; 1879, № 32; 1880, № 25; 1892, № 29].

Lustracje województwa podlaskiego 1570 i 1576, wyd. J. Topolski i J. Wiśniewski, Warszawa-Wrocław 1959.

Matus I., Obraz Cerkwi unickiej w obwodzie białostockim na poczatku XIX wieku, "Studia Wschodniosłowiańskie", Białystok 2015, T. XV.

Matus I., Schylek unii i proces restytucji prawostawia w obwodzie białostockim $w$ latach 30. XIX wieku, Białystok 2013.

Mironowicz A., Monaster Przemienienia Pańskiego w Puszczy Narewskiej, [w:] "Białostocczyzna", Białystok 1990.

Mironowicz A., Życie monastyczne w Rzeczypospolitej, Białystok 2001.

Nacyjanalny histaryczny arxiŭ Biełarusi ŭ Hrodnie, f. 135, op. 1, d. 75 [Нацыянальны гістарычны архіӱ Беларусі ӱ Гродне, ф. 135, оп. 1, д. 75].

Narodowy Instytut Dziedzictwa: Rejestr zabytków nieruchomych. Woj. Podlaskie-powiat hajnowski (Klejniki, cerkiew pw. św. Mikołaja w Koźlikach nr rej.: 674).

Narodowy Instytut Dziedzictwa: Rejestr zabytków nieruchomych. Woj. Podlaskie-powiat hajnowski (Klejniki, kaplica prawosławna cmentarna pw. Przemienienia Pańskiego, 1912, nr rej.: A-533).

Narodowy Instytut Dziedzictwa: Rejestr zabytków nieruchomych. Woj. Podlaskie-powiat hajnowski (Klejniki, kaplica prawosławna pw. św. Mikołaja Cudotwórcy, k. XIX, nr rej.: A-534 z 13.08.2013).

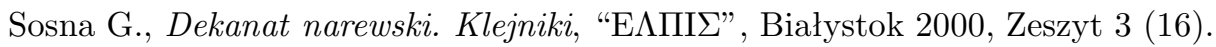

Sosna G., Klejniki, "Wiadomości Polskiego Autokefalicznego Kościoła Prawosławnego", Warszawa 1987, № 1.

Sosna G., Parafie prawostawne. Na poczatku była kelia, "Tygodnik Podlaski", Warszawa 1991, № 7-8/91.

Sosna G., Troc-Sosna A., Cerkiewna własność ziemska na Białostocczyźnie w XVXX wieku, Białystok 2004. 
Sosna G., Troc-Sosna A., Łosinka. Parafia na skraju Puszczy Ladzkiej, Bielsk Podlaski-Ryboły 2009.

Sosnovskij F., Osvjaščenije Klienikskoj Vozniesienskoj cierkvi, Bielskaho ujezda, 4-ho sientiabrja, LEV, 1883, № 40 [Сосновскій Ф., Освященіе Кленинской Вознесенской черкви, Бъльскаго уюзда, 4-го сентября, ЛЕВ, 1883, № 40].

Spravočnaja kniga Grodnienskoj jeparxii na 1905 god, Grodno 1905 [Справочная книга Гродненской епархии на 1905 г., Гродно 1905].

Stankiewicz D., Dobra utracone. Zabytki ruchome w cerkwi w Koźlikach, [w:] "Biuletyn Konserwatorski woj. białostockiego", Białystok 1995.

Wojewódzkie Archiwum Państwowe w Lublinie, Wizyty dekanatu bielskiego, cerkiew klejnicka, syg. 780, k. 402-403

\section{SUMMARY}

\section{A HISTORICAL OVERVIEW OF SACRED BUILDINGS IN THE ORTHODOX PARISH OF THE ASCENTION OF THE LORD IN KLEJNIKI}

The article is an attempt to present certain events over the past centuries connected with the creation of sacred buildings in the Orthodox parish in Klejniki. The article gives the chronological dates of the construction of every place of worship, often presenting their material fittings, such as icons, liturgical texts, etc. The material presented is also enriched with notes on clergymen carrying out pastoral duties in Klejniki parish, and their spiritual contribution to parishioners' life.

The parish life did not avoid various problems connected with an attempt to build churches. The lack of money, difficulties with an access to building materials, and administrative problems caused significant delays in construction work.

Key words: Klejniki parish, sacred buildings, sacred architecture, clergy, material fittings of churches. 